\title{
Prioritások meghatározása a jövőre
}

\section{Szerzői információ:}

Anne Palkamo

Mérnök és a vállalati kommunikációmenedzsment szakértôje, a finn technológiai és innovációs projektek finanszírozásával foglalkozó ügynökség (Finnish Funding Agency for Technology and Innovation, Tekes) kommunikációért felelôs ügyvezetố igazgatója. A Tekes képviselójeként részt vesz a HighTech Finland címú kiadvány és hálózati honlap szerkesztóbizottságának munkájában. E-mail: anne.palkamo@tekes.fi

Így hivatkozzon erre a cikkre:

Palkamo, Anne. „Prioritások meghatározása a jövőre”.

A folyóiratban közölt müvek

a Creative Commons Nevezd meg! - Ne add el! - Így add tovább! 4.0

Nemzetközi Licenc feltételeinek megfelelöen használhatók. 
Anne Palkamo

\section{Prioritások meghatározása \\ a jövôr e}

A FinnSight 2015 program szakértôi megvizsgálták a finn gazdasági életre és a finn társadalomra alapvetố hatást gyakoroló tényezóket, valamint az innováció és a kutatási tevékenység elő́tt álló jövóbeli kihívásokat.

A legkiemelkedóbb területek a fenti szempontokból a következók voltak: a globális kockázatok kezelése, az energiával és a környezettel kapcsolatos kérdések, az egészségügyi ellátási rendszer megújítása, továbbá az IKT és a biológiai tudományok terén elért eredmények alkalmazásai. Mindezek a tudomány és a technológia képviselốinek együttmúködését kívánják meg, az emberi igényekre alapozottan.

A projektben 120 vezetố finn szakember vett részt, a kutatást a finn technológiai és innovációs projektek finanszírozásával foglalkozó ügynökség (Finnish Funding Agency for Technology and Innovation, Tekes) és a Finn Tudományos Akadémia szervezte meg. A projekt 2005-ben és 2006-ban tíz nagyobb témakörre terjedt ki, amelyeken belül összesen nyolcvan olyan szakmai területet határoztak meg, amelyekre Finnországban koncentrálni kell.

A FinnSight 2015 fớ témakörei az alábbiak voltak:

- Tanulás és a tanuló társadalom

- Szolgáltatások és szolgáltatási innovációk

- Jólét és egészségügy

- Környezet és energia

- Infrastruktúra és biztonság

- Bioszakértelem és biotársadalom

- Információ és kommunikáció

- Kölcsönös megértés és emberi kölcsönhatások

- Anyagok

- Globális gazdaság

\section{Az emberi és társadalmi tényezők kellő gondossággal való számításba vétele}

„Az emberek mint fogyasztók és végfelhasználók egyre inkább központi szerepet játszanak az innovációban. Munkánkat az emberi szempontoknak megfelelólen és az emberekért végezzük, figyelembe véve az alapvetố emberi és társadalmi tényeket. Ez megkívánja a társadalom- és viselkedéstudományok múvelóinek, valamint az innovációs tevékenységben szerepet játszó kulturális kérdések szakembereinek, továbbá a gazdasági szakértốknek és a technológia fejlesztôinek a közremúködését. Szükség van a 
különbözófajta készségekkel és tudásvagyonnal rendelkezố szakemberek együttmúiködésére, és itt különösen hangsúlyozandó az interakció és a tanulás jelentôsége" mondta Pirjo Kyläkoski, a Tekes jövókutatási igazgatója.

„A jólét növeléséhez új megoldásokra és strukturális változásokra van szükségünk társadalmi alrendszereinkben, mivel az a veszély fenyeget, hogy az egészségügyi ellátás költségei a népesség elöregedése miatt meghaladják jelenlegi lehetốségeinket. Az egészségügyi ellátás terén az új megoldások és új szolgáltatási koncepciók kidolgozásához még inkább kutatásbarát atmoszféra megteremtésén és különféle egészségfejlesztési programok végrehajtásán keresztül fog vezetni az út. Ehhez nélkülözhetetlen az állami és a magánszektor együttmúködése" - mutatott rá Pirjo Kyläkoski.

\section{A jövő építőelemei}

Az egyes témakörök kutatói hangsúlyozzák, hogy alapvető fontosságú az olyan jellegú szakmai tudásvagyon gyarapítása, amely lehetôvé teszi a tudományos áttöréseket és a technológia ugrásszerú fejlesztését. Számos ilyen terület, köztük az információs és kommunikációs technológia is alapvetố szerepet tölthet be abban, hogy új típusú gazdasági szemlélet és más újszerú megközelítések jussanak érvényre a szolgáltatási vállalkozásokban. Az információs és kommunikációs technológiák alkalmazásai sokféle vonatkozásban növelhetik a termelékenységet a magánvállalatoknál és azállami szektorban egyaránt. Itt a szoftver, az információs hálózatok, a mobilkommunikáció, az új szolgáltatások és a tartalomfejlesztés kérdéseivel összefüggố szaktudás játszik központi szerepet. A lehetốségek bóségesen adottak valamennyi üzleti és iparági klaszterben, az egészségügyi szolgáltatásoktól a távérzékelési (remote sensing) és a nehézipari alkalmazásokig.

A mindenütt elérhetôvé váló információszerzési és távközlési lehetôségekre alapozott szolgáltatások igen gyorsan fognak fejlődni. A kulcsszavak ebben a tekintetben a valós idejú információ, a többnyelvúség, a helyi sajátosságok figyelembevétele, valamint a célzott és személyre szabott szolgáltatás.

A projekt résztvevốinek véleménye szerint Finnországban a világ élvonalához tartozó szakmai tudásvagyon áll rendelkezésre három kulcsfontosságú ágazatban: az információs, az erdógazdálkodási és a kommunikációs szektorban. A döntố tényezô az, hogy ezeknek a szektoroknak mennyiben sikerül együttmúködniük új megoldások és új termékek kifejlesztésében. Az optikai és elektronikai ágazatokban például a nyomtatott áramkörök teljesítményének fokozása kövezheti ki az utat a különféle száloptikai alapú termékek és elektronikus médiumok, valamint a hibrid médiumok kifejlesztéséhez. Az ilyen típusú innovációk jelentốs hozzáadott értéket produkálnak a fogyasztói szolgáltatásokban, az információszerzés terén, az elektronikus kereskedelemben, az oktatásban, a marketingtevékenységekben, valamint a szórakoztatás és egyéb szabadidốs szolgáltatások területén is. A hibrid média olyan multidiszciplináris kutatási területet jelent, ahol nem csupán a technológiai know-how iránti kereslet nyilvánul meg, hanem a végfelhasználók kommunikációs szükségleteire és viselkedésére vonatkozóan folytatandó kutatásokra is szükség van. 


\section{A globális gazdaságban innovációra van szükség}

A globális kockázatkezelés egyre nagyobb fontosságra fog szert tenni a jövóben. A gazdaságot, a környezetet, az energiaellátást, az infrastruktúrát és az egészségügyi ellátást érintố kockázatok csökkentése érdekében elsôsorban jobb ellenôrzésre és jobb elörejelzésekre van szükség. A kutatási és innovációs tevékenységek terén lépéseket kell tenni a globális tudás és a kulturális know-how alkalmazására.

A jövóbeli prosperitás szempontjából különösen nagy figyelmet érdemel a szolgáltatások fejlesztése és exportálható termékké tétele. Ebben a tekintetben bơséges lehetôségek kínálkoznak az egészségügyi ellátás, az idősek számára juttatott jóléti szolgáltatások, a nagy-és kiskereskedelem, valamint az ipari szolgáltatások terén egyaránt. Ezeknek a lehetôségeknek a kiaknázásához multidiszciplináris fejlesztési programokra, az IK'T alkalmazási lehetôségeinek és a felhasználói igényeknek a felismerésére irányuló erôfeszítésekre és az új elgondolások tesztelésére van szükség. Azok lesznek a sikeres szolgáltatások, amelyek integrálni képesek többek között a társadalmi, a kereskedelmi, a szervezési, a technológiai és a tervezési szaktudást.

A különféle gazdasági ágazatok és az egyes vállalkozások, valamint a tudomány és a technológia fejlődése szempontjából is egyre fontosabb szerepet fog játszani a globális szinten felhalmozódó tudásvagyon kiemelkedó hatékonysággal való felhasználása és gyakorlati alkalmazása. Ahhoz, hogy a kutatás élvonalában maradhasson, Finnországnak jól fel kell készülnie a változásokra, és rendelkeznie kell a nemzetközi fejlemények monitorozására, valamint a globális tudásvagyon átvételére és felhasználására alkalmas mechanizmusokkal. A globális gazdaságban növekednek a nemzetközi kockázatok, amelyeknek az információs, a telekommunikációs és az energiahálózatok vannak leginkább kitéve. Ezekhez kapcsolódik a szabályozás szakterülete, ahol tág lehetôségek nyílnak nemzetközi együttmúködés keretében folytatandó, máris idốszerú vagy várhatóan hamarosan aktuálissá váló kutatási, fejlesztési és innovációs tevékenységre. Az energiával és a környezettel kapcsolatos kérdések globális szinten kritikus fontosságúak, ennélfogva jelentốs befektetésekre van szükség az energiatermelés új módozatainak kifejlesztése és használatbavétele, valamint a fenntartható környezetgazdálkodás és az innovatív környezetvédelmi technológiák terén is.

A fenntartható fejlôdést biztosító megoldások elótt növekvő kihívások állnak, és ugyanakkor új piacok alakulnak ki, különösen a városi környezetek, az ivóvíz-ellátási rendszerek és a víztisztítási technológiák tekintetében. Kínában már folyamatban vannak a tervezési munkálatok és elózetes kísérletek az úgynevezett ökovárosok (ecocities) felépítéséhez, és már Európában is létrejöttek ökokerületek egyes városokon belül. Ezen a területen átfogó jellegú, általános megközelítéssel lehet versenyelónyhöz jutni, ugyanis itt kiemelt szerephez juthatnak a közösségtervezést, az energiaellátást és a hulladékkezelést, a szállítást és közlekedést, a logisztikát, valamint a biztonságos és jó minőségú környezet kialakítását is felölelő integrált rendszerek. 


\section{Versenyelőnnyé válik az energiahatékonyság}

Az energiaszektorban egyre fontosabbá válnak a megújítható energiaforrások. Finnország kedvezó helyzetben van a biomassza energiaforrásként való felhasználásához. A fafeldolgozó iparágakban már ma is használnak bioüzemanyagokat.

A faipari melléktermékek felhasználhatók üzemanyagok elóállítására, és az erre szolgáló technológia fejlesztése jelentősen hozzájárulhat a foglalkoztatottság növeléséhez és a nemzetgazdaság egészének gyarapításához. Az erdógazdálkodásra épülố iparágak megfeleló platformot nyújthatnak a fejlettebb bioüzemanyag-finomítási eljárások kifejlesztéséhez is.

Számos termék és alkalmazás hatékonysága könnyen növelhető egyötöd részével, sốt akár 50\%-kal is. Az energiahatékonyságot a termékek elsôrendú fontosságú jellemzójének kell tekinteni. Az alacsony építésú lakóházak hốvesztesége és energiafogyasztása már a tervezési fázisban csökkenthetố. Végsố célként ezen a téren olyan elốre gyártott elemekból készült lakóházak kifejlesztésére érdemes törekedni, amelyekben különféle technológiák integrált alkalmazása révén gyakorlatilag kiküszöbölhetô minden energiaszükséglet és energiaveszteség.

A megújuló energiaforrások kihasználása érdekében számos új fenntartható energiatermelési módszer van jelenleg fejlesztési fázisban vagy már gyakorlati kipróbálás alatt. Bioüzemanyagok gyártásához az olajtartalmú növények termesztése kínálja a legrövidebb utat. Törekedni kell a lehetô legmagasabb hektáronkénti hozamot biztosító növényfajták megtalálására. A bioüzemanyag-termelés fejlesztésében fel kell használni a botanika és a növénynemesítés, valamint a genetikai módosítások terén elért eredményeket egyaránt.

Az energiaellátási problémák terén a kisebb, decentralizált megoldásokra fordított befektetések gyorsabban szaporodnak, mint azok, amelyek a nagyobb erómúvek fejlesztésére szolgálnak. Jelentốs érdeklődést váltanak ki például a 10-20 kilowattos tartományba esó alkalmazások. Ígéretes terület továbbá az üzemanyagcellák vagy üzemanyagsejtek (fuel cells) fejlesztése és alkalmazása, valamint a napenergia hasznosításával folyó hố- és elektromosáram-termelés, a decentralizált energiatermelés egyik leggyorsabban fejlôdố területe. A napenergia kiaknázása olyan exportpiacot jelent, ahol a jövóben minden bizonnyal erós kereslet fog megnyilvánulni mind az alkalmazások, mind a rendszer-specialisták iránt.

Az ipari létesítményekben jelentốs mennyiségû́ energia, úgynevezett hulladékhô megy veszendóbe. Ez környezetbarát módon hasznosítható lehet többek között üvegházakban is.

A nanorészecskékkel foglalkozó tudományágak és a nanotechnológia terén jelentôs munkálatok folynak a sejtméretû komponensekkel folytatott eljárások tökéletesítésére: a nanotechnológia nagymértékben hozzájárulhat az automatizált vezérlés hatékonyságának növeléséhez.

\section{Új lehetőségek nyílnak az innovációra}

A globalizáció folyamatosan megváltoztatja a világot. A tömegtermelésre berendezkedett iparágak gyakran azokban az országokban jutnak versenyelönyhöz, ahol alacsonyak a munkaeróköltségek. Finnországban és más fejlett országokban ugyanakkor 
új innovációs lehetốségek nyílnak meg a meglevố kompetenciák és speciális gazdasági elgondolások hasznosítása elốtt. Az innovációk olyan új múk ködési modellben érvényesülhetnek, amely fenntartható versenyelónyt hoz létre. A tudományos és technológiai szaktudáson kívül ehhez kulturális, pénzügyi és üzleti bátorságra, valamint kapcsolatépítési kompetenciára is szükség van, ami különféle társadalmi képességeket, együttmúködési és interakciós készségeket és nyitott kommunikációt foglal magában. Egyre növekvő igény nyilvánul meg az úgynevezett „nyílt innovációkra”.

„Az innovativitáshoz hozzátartozik a folyamatos megújulás, ami lehetővé teszi, hogy az új lehetôségeket nyíltan, együttmúködő módon tárjuk fel, úgy, hogy ezek a folyamatok minden közremúk ödốt nyerô helyzetbe juttassanak. A sikerhez arra van szükség, hogy a munka résztvevói mindannyian elsajátítsák ezt a megközelítést, és minden egyes közremúködő személyes feladatának tekintse az alkalmazkodást az együttmúködés, az interakció és a nyílt kommunikáció új formáihoz, nemzeti és globális szinten egyaránt. A menedzsment és a vezetés szintjén szintén megújulásra van szükség. A FinnSight 2015 felhívja az egész globális innovációs hálózatot, hogy vegyen részt ebben a megújulási folyamatban” - mondta Pirjo Kyläkoski.

\section{A FinnSight mint a Tekes stratégiai munkáiának része}

„A FinnSight 2015 címú elốrelátási (foresight) projekt részét képezte a Tekes folyamatosan végzett stratégiai tervezési munkájának: ez fektette le az alapokat a tudomány, a technológia és az innováció stratégiai központjainak (Strategic Centres for Science, Technology and Innovation) létrehozásához - írta Pirjo Kyläkoski. - Pillanatnyilag éppen a Tekes stratégiájában központi szerepet játszó területeket határozzuk meg. Ez nagyon interaktív folyamat. Partnereinkkel együtt a jövő vízióit dolgozzuk ki az innováció tekintetében, és utakat jelölünk ki a kitúzött célok eléréséhez. Új stratégiánk középpontjában az igen erốsen fogyasztóorientált megközelítés, az innovációs tevékenység megújítása, a globális értékhálózatok, az állami és a magánszféra kapcsolatai (Public-Private Partnership, PPP), valamint az információs és kommunikációs technológiák mint új üzleti tervek és elgondolások kialakítását elősegítő eszközök állnak."

\section{További információ:}

Pirjo Kyläkoski

foresight manager

pirjo.kylakoski@tekes.fi

tel.: +358106055795 vagy +358505577795

www.finnsight2015.fi

www.tekes.fi 